機皮膜の付着性に多く関与すると思われる表面粗度の限 界を，電子顕微鏡のレプリカに特けるアセチルセルロー ズ皮膜の忠実性から類推し，付着性の本質を論議した。 その結果を要約すれば，

1）リン酸浴による陽極酸化膜には，有機皮膜の付着 強度がいちじるしく大で, 硫酸およびシュウ酸浴のそれ の10ないし10数倍の付着力を示す。ただし高温度および 高濃度による陽極酸化膜には付着性は必ずしもよくな い。

2）有機皮膜の付着性は，みかけの表面アラサよりむ しろ微細粗度がより大きく関与するもののようで, リン 酸浴による陽極酸化皮膜はその条件にかなっている。

3）以上の結果は，陽極酸化皮膜への電着に打ける付 着性の場合とよく一致する。
終りに本研究に終始協力された山口春千代堙に感謝す る。

（本論文はアルミニウムの陽極酸化膜への電着に関する 研究の第 7 報とする。)

（昭和33年6月, 本協会春季講演大会にて発表）

(1958-12-24受理)

文献

(1) 為広, 吉田, 工化, 58, 870 (1955)

(2) 麻田，嵓内，本誌，6，24（1955）

(3) 井上, 工化, 51, 161 (1948)

(4) 著者，本誌，8，185 (1957)

(5) 著者，本誌，9，213（1958）

(6) F. Keller, M. S. Hunter and D. L. Robinson, J.

Electrochem. Soc., 100, 411 (1953)

\title{
鉱油の冷却果効の測定法とその比較について
}

原謙 次 郎*

\section{On Comparison of Measurement Method of Quenching Quantities of Mineral Oils Kenjiro HARA*}

Quenching curves of the test pieces of silver, carbon steel and stainless steel in the 150\# spindle oil were investigated, and the effects of quenching were compared. The results are as follows.

The silver method is most accurate, and most suitable of all oils in the comparison of quenching properties. The carbon steel method is practical, but less accurate. By the above two methods the quenching properties only of the surface of the specimen can be measured. However, it is characteristic that by stainless steel method the quenching propeties of the whole body can be measured.

\section{1. 緒言}

各種の冷却剤の冷却能力を測定する方法には主として 金属の温度の時間による降下度，すなわち冷却曲線を測 定している。油を主体とする冷却剂においても同様であ る。しかしその泠却の対象を狭義にとって，たとえば溹 入油や焼モドシ油のみを考えるときは，むしろ硬化能力 または硬化深度その他機械的強度などを測定する方法が 直接的であるが，一般に冷却曲線を求めこれと焼入硬度 との関係を求める方法が広く採用されている。しかした んに冷却能力のみを直接目的とする場合には，当然冷却 性能の大小は冷却曲線または瞬間冷却速度によって判断

†本稿は「鈗油の冷却効果飞関する研究」の第 1 報で ある。

* 日本油化学工業株式会社 (大阪市城東区今福中) Nippon Yukagaku Kōgyo Co. Ltd.
しなければならない。したがってこの方法として大別す ると

a）熱電対の熱起電力の变化を利用

b）金属線の電気抵抗の変化を利用

c）金属棒の伸びの変化を利用

の3種にわけられる。したがってこれらの方法を利用し て，テストピースとしても炭素鋼，ステンレス，銀の三 つの特色ある金属を選び，金属表面温度または金属全体 の平均温度を測定して各方法の比較を試みた。

\section{2. 測定方法の比較}

測定方法として第 1 表の 3 方法を採用し，第 2 表のよ らな条件によってテストした。

試片温度および油温は他の温度でも測定したが，主と して使用した温度条件である。3方法のいちじるしい相 違点は材料の差違, 測定温度位置の差, おょび油量の大 
第 1 表 冷却曲線測定方法の比較

\begin{tabular}{|c|c|c|c|c|}
\hline 記号 & 理 & 試片 & 定 & 者 \\
\hline A & $\begin{array}{l}\text { 熱電対の熱起電力の } \\
\text { 変化の利用 }\end{array}$ & 炭 素 鋼 & 原 ${ }^{1)}$ 他 & \\
\hline B & $\begin{array}{l}\text { 金属棒の伸びの変化 } \\
\text { 利用 }\end{array}$ & ステンレス & 佐藤 ${ }^{2)}$ 他 & \\
\hline $\mathrm{C}$ & $\begin{array}{l}\text { 熱電対の熱起電力の } \\
\text { 変化の利用 }\end{array}$ & 銀 & $\begin{array}{l}\text { 多賀谷・田村 } \\
\operatorname{Rose}^{3)}, \text { Peter }^{6} \text { ) }\end{array}$ & Lange $^{4)}$, \\
\hline
\end{tabular}

第 2 表 測 定条件の比較

\begin{tabular}{|c|c|c|c|c|c|c|}
\hline 記号 & 試 片 & $\begin{array}{c}\left(\begin{array}{c}0 \\
\text { 片の大キサ } \\
(\mathrm{mm})\end{array}\right. \\
\end{array}$ & $\begin{array}{r}\text { 油量 } \\
(l)\end{array}$ & 油量/試片 & $\begin{array}{c}\mid \begin{array}{c}\text { 試片温度 } \\
\left({ }^{\circ} \mathrm{C}\right)\end{array} \\
\end{array}$ & 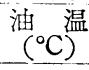 \\
\hline A & 崖 素 鋼 & $5 \times 70$ & 1 & 83 & 850 & 40 \\
\hline B & ステンレス & $5 \times 70$ & 18 & 1500 & 850 & 40 \\
\hline $\mathrm{C}$ & 銀 & $10 \times 30$ & 0.3 & 11 & 800 & 80 \\
\hline
\end{tabular}

壊温度の発生する時間的おくれのために 対流部もそれだけおくれている点と, 油 温が $80^{\circ} \mathrm{C}$ で他の方法より高温であるから である。なお後述するように炭素鋼のA 法では，とくに気泡発生部分は曲線に微 小の凹凸を示し，対流部にはいるとほと んど認められない。B柱般的になだら かな曲線を示しているが，これは表面温 度ではなく金属全体の伸びを利用してい るためである。

\section{4. 瞬間冷却曲線の比較}

第 1 図の冷却曲線より瞬間冷却曲線を 示すと第 2 図のと抢りである。

炭素鋼の A 法では気泡部とくに $550^{\circ} \mathrm{C}$ 以上の蒸気膜段階に拈いては，いちじる
小したがって油量 : 試片（重量比）のちがいである。油 はパラフィン系の 150 ス スピソドル油で, 比重0.890, 色 相 -1 , 引火点 (P.M.) $194^{\circ} \mathrm{C}$, (C. O.C.) $375^{\circ} \mathrm{F}$, 粘 度 (R.W.) $68 \mathrm{sec}\left(@ 50^{\circ} \mathrm{C}\right)$, (S.U.S.) 40.0 sec (@ $\left.210^{\circ} \mathrm{F}\right), 113 \mathrm{sec}\left(@ 100^{\circ} \mathrm{F}\right)$, 凝固点 $-12.5^{\circ} \mathrm{C}$, 表面張力 36.0 dyne $/ \mathrm{cm}\left(@ 30^{\circ} \mathrm{C}\right)$, 比熱 $0.452\left(@ 40^{\circ} \mathrm{C}\right), 0.468$ $\left(@ 60^{\circ} \mathrm{C}\right)$ である。油はカクハンせずに静止状態にて使 用した。

\section{3. 冷却曲線の比較}

第 1 図に三つの方法にて測定した冷却曲線を示す。炭 素鋼の表面温度（A法）は，はじめごく短時間に急激に 低下し以後若下緩慢な泠却となり，さらに $600^{\circ} \mathrm{C}$ 付近よ り泠却速度がはやくなって核沸騰段階にはいり，以後4 sec の $350^{\circ} \mathrm{C}$ 付近より対流段階にはいるような冷却曲線 を示す。ステンレスの伸びの利用（B法）は，はじめ短 時間はなだらかで泠却は拉そく，つぎに急な冷却低下を 示し同様に対流段階にはいる。したがって $1 \mathrm{sec}$ までは $\mathrm{A}$ が早く, 以後 $4 \mathrm{sec}$ まではBが冷却性大で, それ以後 の対流部は大差がない。銀の表面温度（C法）は $570^{\circ} \mathrm{C}$ の $2.5 \mathrm{sec}$ まではほぼ直線的に低下し，その低下度はA

・Bより扣そく, 前記温度および時間で急激に曲線が変 化し冷却速度が大となり核沸騰段階にはいり, 以後变移 点より対流段階の緩慢な徐冷期にはいる。したがって銀 による方法が泠却能力は一番低い結果 を示しているが，蒸気膜段階と核沸騰 段階の変移点はもっとも鋭敏で，した がって，気泡発生部分の泠却もはやい が，対流部はいずれの方法も大差な い。ただしC法が同一時間ではやや高 目になっている点は，C法は蒸気膜崩
しい冷却速度の起伏があって気泡発生がなくなるととも になめらかな曲線となる。したがってこの起伏の数は冷 却曲線の凸山の数を示し, その起伏の高低拉よび幅は冷 却曲線の凸凹の大きさを示すことになる。ステンレスの 伸びの利用のB法は，感度が鋭敏でないために全体にな めらかな，ある温度で最高を示すような瞬間泠却速度曲 線となり，この場合は $600^{\circ} \mathrm{C}$ の時最高で, その速度は $260^{\circ} \mathrm{C} / \mathrm{sec}$ であった。

銀棒の表面温度法のCは，蒸気膜段階は直線または一 つか二つの大きな起伏を示すような，ほとんど直線に近 い形となり，蒸気膜崩壊温度で急上昇して不連続とな り，非常に大きな瞬間冷却速度を示すが，核沸騰部では 急激に減少して $300^{\circ} \mathrm{C}$ 付近からは，いずれの方法も大差 なく，きわめて低速度で温度が低下してもその差はな い。これは対流段階にはいったことを意味する。

\section{5. 結 論}

$\mathrm{A}$ 法の炭素鋼の表面温度の測定法は，とくに膜沸騰部 において鋭敏に变化し，冷却曲線および瞬間冷却速度曲 線におうとつを生ず。これは炭素鋼は加熱によって, 黒 色の酸化皮膜を生 じ，これが冷却中 脱落するが，その 酸化皮膜の性質，

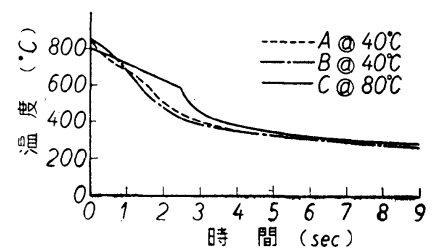

第 1 図各測定法による冾却曲線

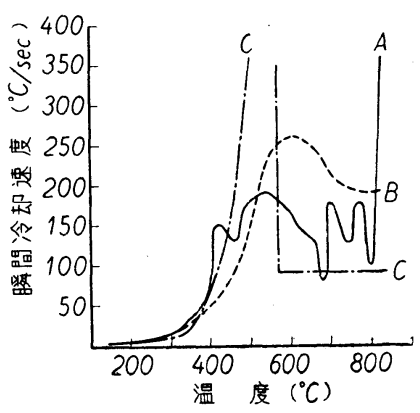

第2図 各測定法による僢間 椧却曲線 
厚サ, 脱落時期の不均一性が，とくに蒸気膜段階の冷却 に影響するためである。したがってこの方法は感度は鋭 敏であるが，上記のさけがたい性質のために不均一にな りやすく，一回使用すれば酸化皮膜形成の部分だけ直径 は小さくなり，熱電対の取付方法がもずかしい点などの 欠点を有している。しかし，烸入レに使用されるのはほ そんど炭素鋼であるためで実用的で直接的な試験方法で ある。

$\mathrm{B}$ 法のステンレス鋼の伸びの利用はとくに蒸気膜段階 のはっきりした線がなく，一般に気泡段階と対流段階に 二大別される。一般に冷却曲線および僢間冷却速度曲線 はなめらかである。これは他の 2 方法が表面温度の測定 であるのに対し，熱変態点のない点を利用して，その伸 びによる方法であるから金属全体の温度を示すことにな り, 表面温度にくらべ時間的のおくれやずれを生じ感度 は落らる。しかし焼入レや金属全体に関する考察を行な う場合には適している。

C 法の銀棒の表面温度はとくにはっきりと蒸気膜段階
と核沸騰段階を区別し, 蒸気膜崩壊温度とその発生時間 は冷却性の大小をきめる大きな要因をなしている。感度 は良好で再現性もよい。ただ銀棒であるために材料とし ては適切ではないが，冷却剂の立場から冷却性の大小を きめたり，その泠却能の特色を把握する研究には良好な 手段である。

\section{交献}

（1）原謙次郎，日本化学会第 9 年会講演，13053

（2）佳藤清吉，金属の研究，9，174（1932)，理科報告， 20, 260 (1931)

（3）多賀谷，田村，日本金属会学誌， B-15 11，535（1 951)

(4) K.G.Speith and H.Lange, MittKao-with, Inst Hisenfarsh, 17, 175 (1935)

(5) A.Rose, Arch. Eisenhüttenwess, 13, 345(1939/ 1940)

(6) W.Peter, Arch. Eisenhüttenwess, 20, Heft 718, 263 (1949)

\section{鉱油の冷却効果についで}

原謙 次 郎*

\section{Studies on Quenching Properties of Mineral Oils}

\section{Kenjiro HARA*}

The quenching curves of the test pieces of silver, carbon steel and stainless steel in all kinds of lubricating oils, paraffine and naphthene series ranging from light oil to superheated cylinder oil were investigated. The results are as follows :

The quenching curves consist of vapour film stage(I), nucleus boiling film part (II) and convection stage(III). The quenching properties become characteristic at the point of vapour film collapse temperature $\left(T_{1}\right)$ on the boundary between (I) and (II), time $\left(\tau_{1}\right)$, and convection begining temperature $\left(\mathrm{T}_{2}\right)$.

The best result is obtained when the time of (I) is short, the width of (II) large and (III) low. The range of quenching chracteristics of mineral oils is from $350^{\circ}$ to $750^{\circ} \mathrm{C}$ of $T_{1}, \tau_{1}$ from 8 to 0.5 seconds, and $\mathrm{T}_{2}$ from $200^{\circ}$ to $500^{\circ} \mathrm{C}$.

$T_{1}$ and $T_{2}$ of heavy oils are higher than those of light oils, consequently, the former is better in the begining, and the latter at the lower temperature than the initial boiling point.

With the same viscosity and temperature, paraffinic oils are better in the begining, and naphthenic oils later. With the same viscosity and different temperature, oils of the bigger molecular weight are better. The quenching curve take the same tendency even though the initial temperature of test pieces is changed.

†本稿は「鉱油の冷却効果に関する研究」の第 2 報である。

*日本油化学工業株式会社（大阪市城東区今福中） Nippon Yukagaku Kōgyo Co. Ltd. 